\title{
Benefit-Cost Analysis of Environmental Projects: A Plethora of Systematic Biases
}

\author{
Philip E. Graves
}

\author{
CESIFO WORKING PAPER NO. 3144 \\ CATEGORY 9: RESOURCE AND ENVIRONMENT ECONOMICS
}

August 2010

\footnotetext{
An electronic version of the paper may be downloaded

- from the SSRN website: Www.SSRN.com

- from the RePEc website: $\quad$ www.RePEc.org

- from the CESifo website: $\quad$ www.CESifo-group.org/wp
} 


\title{
Benefit-Cost Analysis of Environmental Projects: A Plethora of Systematic Biases
}

\begin{abstract}
There are many reasons to suspect that benefit-cost analysis applied to environmental policies will result in policy decisions that will reject those environmental policies. The important question, of course, is whether those rejections are based on proper science. The present paper explores sources of bias in the methods used to evaluate environmental policy in the United States, although most of the arguments translate immediately to decision-making in other countries. There are some "big picture" considerations that have gone unrecognized, and there are numerous more minor, yet cumulatively important, technical details that point to potentially large biases against acceptance on benefit-cost grounds of environmental policies that have true marginal benefits greater than true marginal costs, both in net present value terms. It is hoped that the issues raised here will improve future conduct of benefit-cost analyses of environmental policies.
\end{abstract}

JEL-Code: C91, D12, D61, D62, D78, D81, H11, H41, H43, Q20, Q30, Q51, Q58.

Keywords: benefit-cost analysis, environmental policy, decision making, choice behavior, public goods, willingness-to-pay, willingness-to-accept, precautionary principle, hedonic methods, sum of specific damages, health effects model, environmental perceptions.

\author{
Philip E. Graves \\ Department of Economics \\ University of Colorado \\ USA - Boulder, CO 80309 \\ Philip.graves@colorado.edu
}

I would like to acknowledge the support of CESifo in Munich, Germany where I wrote this paper during a delightful three week visit in the summer of 2010. I have received helpful comments on related work from many individuals and at a large number of seminars in the United States and Canada. I retain responsibility for any errors of omission or commission. 


\section{Introduction}

After several decades of research in environmental economics, it has become increasingly clear to me that benefit-cost analysis of environmental policies - as currently practiced in the U.S. and elsewhere - is strongly biased against acceptance of those policies. The purpose here is to bring together in one place as many arguments as possible to bolster this position in order to provide grist for discussion. It is hoped that such discussion will yield improved methods for the conduct of future benefit-cost analyses in the environmental area.

The nature of the biases against adoption of environmental policies are many, ranging from a potentially serious unrecognized theoretical problem of public good valuation to specific technical details of the valuation methodologies in use. Section II briefly discusses a flaw in public good valuation generally, noting that this flaw is likely to be of particular importance in the environmental policy setting. Special interest power is seen to be concentrated against potential environmental policies vis-à-vis other policies (e.g. national defense) where special interest power promotes policy adoption. This section presents a "big picture" argument for a bias against environmental programs.

Section III also deals with a big picture issue. This section examines the implications of the - potentially clashing — motives that underlie marginal willingness-to-pay for environmental quality, concluding that the common valuation methods of economics are generally biased toward "use values" versus "non-use values."

Section IV turns to a host of "little picture" specific methodological flaws in environmental valuation that collectively imply significant and systematic bias against adoption of environmental policy. Section $\mathrm{V}$ concludes, finding that there is compelling evidence that environmental benefit-cost analysis is biased against the environment. 


\section{Valuing Environmental Public Goods}

As discussed in extensive detail in Graves (2009), a flaw in public goods valuation has gone unrecognized for over a half-century. Early in Samuelson's (1954) well-known paper characterizing the nature of optimal public goods provision, he notes that inputs are just like outputs except for a minus sign in front of them-we want more output from fewer inputs. Later in this famous contribution, Samuelson notes that it will be extremely difficult in practice to observe the demands for public goods, because individuals have no incentive to voluntarily reveal their demands, rather having an incentive to "free ride." This renders collective decisionmaking about public goods levels very difficult.

However, in any situation in which there is an incentive to free ride in output markets, there will also be an incentive to free ride in input markets. That is, ${ }^{1}$ since we work to acquire the goods that we desire, if a class of goods (e.g. public goods) cannot be individually incremented from work effort, that effort will not be undertaken since leisure is valuable. Individuals will work to pay for whatever amount of the public good happens to be provided, but is it likely that the proper amount of the public good will be provided?

For some public goods, such as national defense, special interest power is likely to promote the provision of battleships, tanks, aircraft, missiles and the like. The potential providers have an incentive to portray their goods in a positive light and to lobby Congress in various ways to obtain contracts making provision profitable. The amount of such goods provided might very well be the right amount or perhaps too much as is emphasized by the public choice literature. Whatever amount of such goods happen to be provided, the costs of

\footnotetext{
${ }^{1}$ See Graves (2009) for detailed discussion: http://papers.ssrn.com/sol3/papers.cfm?abstract id=1119316.
} 
provision, borne by working taxpayers, will result in optimal increases in work effort to pay for such goods along with the private goods desired.

However, the case for environmental public goods is quite different; indeed, for most environmental policy, special interests are likely to be aligned against any policies that would raise the cost of producing goods. Illustrating with but one industry, automobile manufacturers have fought against seatbelt requirements, airbag requirements, and-notably for present concerns - catalytic convertors.

In such cases, regulation will only emerge when the growing demands of a larger and richer populace overcome resistance to government intervention by entrenched special interests and others who on ideological grounds desire limited government. ${ }^{2}$ Any such intervention is likely to begin conservatively with very low provision goals, such as early EPA requirements for exhaust gas recirculation systems for more complete burning, reducing both unburned hydrocarbons (now VOCs) and carbon monoxide, CO.

At conservative initial provision levels, it is likely that a properly-conducted benefit-cost analysis would favor many additional environmental policies. But there is an inherent inability to properly conduct benefit-cost analysis in this case-the non-optimally low initial provision levels will result in a non-optimally low work effort, hence income generated is also nonoptimally low. And, critically, all of the ungenerated income would have been spent on the public good, abstracting from general equilibrium effects. ${ }^{3}$ That is, benefit-cost analyses of

\footnotetext{
${ }^{2}$ I should perhaps point out that I am firmly in this latter camp, in general. I believe that government does so many things it should not be doing at all that it fails to do at all well the things that it should do.

${ }^{3}$ The point is not merely that the justifiable amount of public good provision will be larger if those conducting the analysis recognize that the optimal income generated will be larger at a higher provision level (see Flores and Graves 2008 on endogenizing income in benefit-cost analyses). Rather, the initial income level is wrongly presumed to be an appropriate starting point for the analysis when it is not.
} 
environmental public goods are currently being conducted at the wrong income levels because of free riding in input markets. ${ }^{4}$

What this implies, from a policy perspective, is that the difficulty is not just attempting to solve the well-known demand revelation problem out of a given income. Rather, the initial income is itself inappropriately low because of the fully symmetric, but unrecognized, demand revelation problem in input markets.

As a practical matter, starting from the conservative initial environmental provision level, environmental projects should be accepted even if apparent costs exceed apparent benefits since the actual benefits will be inevitably larger than those perceived out of the given initial income. In other words, when regulators produce increments to environmental quality up to the point where observed marginal benefits equal observed marginal costs out of current income, they are under-providing environmental quality by some unknown, but possibly large, amount. ${ }^{5}$

Existing efforts (see e.g. Clarke 1971, Groves and Ledyard 1977) to solve the demand revelation problem have been largely moot, requiring quasi-linear preferences as but one limitation. The ungenerated income of interest here represents additional, but unobserved, marginal benefits for any environmental good under consideration - the apparent marginal rate of substitution between environmental and ordinary private goods becomes distorted, making environmental goods "look" less valuable on the margin than they are.

Is there any corroborative evidence to indicate that the theoretical problem discussed here may be of any practical significance? Yes. A body of experimental economic research reveals a

\footnotetext{
${ }^{4}$ The more important environmental and other public goods are relative to private goods in the utility function, the less income will be generated, an extreme case being perhaps the "hippie drop-outs" of the sixties. The "lazy" person who desires little in the way of either private or public goods is observationally equivalent to the person who desires very large amounts of public goods and modest amounts of private goods - each might generate the same income, hence are indistinguishable to the benefit-cost analyst.

${ }^{5}$ One might argue that those desiring environmental public goods can pursue other avenues to achieve their goals, perhaps volunteering or engaging in the political system to attempt to "make a difference." However, the same incentive problem plagues these alternatives, hence too little of such efforts is forthcoming.
} 
large gap between willingness-to-pay and willingness-to-accept (see Horowitz and McConnell 2002 for a summary). There might be many reasons for such a gap. ${ }^{6}$ However, the finding by Horowitz and McConnell that the WTA-WTP gap is by far the largest for public goods, suggests the possible importance of the arguments presented in this section. ${ }^{7}$ For example, when contemplating small increments to air quality people will often express quite small marginal willingness-to-pay, but will claim to require order-of-magnitude larger amounts to compensate for equally-small decrements to air quality. The ungenerated income resulting from the input market demand revelation problem would add to the WTP, greatly reducing the gap, and suggesting that WTA might perhaps more closely approximate properly measured WTP.

The public good valuation flaw discussed in this section has further implications for the conduct of benefit-cost analysis beyond the expectation that the benefits in the numerator are understated. As with free riding at a point in time, free riding is to be expected for intertemporal decisions as well. Suppose that the bequest motive is comprised of desires to make our offspring better off, both in terms of wealth comprised of ordinary goods and wealth in the form of an improved environment. To the extent that the latter matters, free riding incentives again suggest that the savings rate will be lower than would otherwise be the case. Those giving bequests will realize that the portion of their bequests that they would like to have devoted to environmental improvement is likely to be negligibly small relative to marginal provision costs. Hence smaller bequests will be made from lower saving rates.

The implication of this is that the social rate of discount in current use for public goods lacking strong special interest support is at least to some extent biased upward. The use of a

\footnotetext{
${ }^{6}$ See Kahneman et al. 1990 or Tversky and Kahneman 1991 for psychological notions of "endowment effect" or "loss aversion." See also Boyce et al. 1992 and Hanemann 1991 for additional explanations.

${ }^{7}$ Plott and Zeiler (2007) argue that the gap is due to faulty experiments; however, their example to establish their position is a private good example, leaving the issue unresolved for public goods.
} 
lower social discount rate for benefit-cost analysis of public goods of this type would result in acceptance of more environmental policies. I suspect that this problem is not of great magnitude, but its importance is largely unknown for the same reasons it is difficult to establish how much free riding occurs in ordinary output or input markets.

\section{The Psychological Underpinnings of Willingness-to-Pay for Environmental Goods}

Economists seldom care "why" people like the goods that they buy, not caring, for example, whether the "ice cube motive" is more or less important than the "fresh produce motive" for purchasing a refrigerator. The only exception to this appears in the money demand literature (the medium of exchange, asset, and precautionary motivations for money holding), but even here it makes no practical difference - the money demand analyst still looks for price and income elasticities in exactly the manner that they would if they completely disregarded why people wish to hold cash.

In the case of the environment, there is a very good reason for examining the various motives that underlie the marginal willingness-to-pay, because there are clashes in the underlying motives that have potentially important policy implications.

The critical distinction is between "use values" (e.g. snowmobiling in Yellowstone Park or observing the sandhill cranes in Nebraska) and "non-use values" (e.g. preservation of Yellowstone Park or leaving undisturbed the sandhill cranes). The non-use values are sometimes further sub-categorized into a) option to use, b) bequest, and c) preservation/existence. The reason that the distinction is critical for present purposes is that the methods used by economists to value environmental resources are best at valuing the use values. ${ }^{8}$

\footnotetext{
${ }^{8}$ As discussed in the following section, being "best" at valuing use values relative to non-use values does not mean that the methods employed by economists are at all good at capturing use values.
} 
By way of illustration, 318 snowmobiles and 78 multi-passenger snowcoaches (usually with 15 passengers each, or 1,070 passengers per day) are currently allowed into Yellowstone each day during the winter. Assuming the winter has 100 days of good snow cover, there would be 31,800 snowmobile and 107,000 snowcoach visitors. If each of the former had a WTP of, say, $\$ 1,000 /$ day and each of the latter a WTP or $\$ 200 /$ day, the aggregate value of winter visitors to Yellowstone would be $\$ 53.2$ million dollars ( $\$ 31.8$ million going to snowmobilers and $\$ 21.4$ million going to snowcoach passengers). This is a quite large amount of use value; moreover there is a fair degree of certainty around this number-it is unlikely to be an order of magnitude larger or smaller.

But the winter visitors also stress the park animals during the harsh winter period when food is scarce and their presence in recent years has resulted in winter park pollution levels rivaling Houston, TX. Continuing the example, suppose that each of the approximately 115 million households in the U.S. would be willing to pay $\$ .50 /$ household/year (about $\$ .20 /$ person/year) to keep Yellowstone pristine in the winter, with cleaner air and less stress on the park animals. If true, the non-use value of the park is $\$ 57.5$ million dollars. Were we equally certain about both the use value numbers and the non-use value numbers, the efficient environmental policy would be to not allow winter visitors to Yellowstone Park. ${ }^{9}$

We are, of course, not equally certain about the two numbers (I pulled the $\$ .50$ preservation value from thin air with no justification at all other than that it seemed "plausible"), because non-use values generally come only from so-called "constructed market" experiments (contingent valuation, conjoint analysis, etc.). Such experiments attempt to elicit values from

\footnotetext{
${ }^{9}$ It should be noted that preservation values might well come from those in other countries, adding value that might be completely ignored by the country contemplating appropriate policy. For example, Americans might have a true willingness-to-pay of a fairly large sum to preserve the habitat of the panda in China or the mountain gorilla in Rwanda, but those values are unlikely to register in those countries.
} 
respondents for a wide range of goods and literally thousands of papers have been published purporting to value various goods, environmental goods being the focus here.

Real controversy about the constructed market approach did not develop until the Exxon Valdez oil spill in March of 1989. Since large amounts of damages were at issue, the debate about the validity of directly elicited valuations became quite heated. ${ }^{10}$ A NOAA panel was convened, headed by two Nobel-prize winning economists (Kenneth Arrow and Robert Solow), with the charge being to determine whether constructed market methods were "capable of providing estimates of lost nonuse or existence values that are reliable enough to be used in natural resource damage assessments."

After many meetings and wide-ranging testimony from experts on both sides of this question, the NOAA panel concluded in a January 15, 1993 Federal Register report that "CV studies [applications of the contingent valuation method] can produce estimates reliable enough to be the starting point of a judicial process of damage assessment, including lost passive use values." However, the report also made specific recommendations about the how constructed market surveys should be conducted that would appear to lead to "conservative" damage estimates, underestimating preservation values rather than overestimating them. The issue is still unsettled and it remains the case that economists and others are strongly divided over whether numbers derived from surveys can legitimately be employed in benefit-cost analysis.

For present purposes, however, there is one point that must be emphasized: the only method currently available for the determination of preservation/existence values is that of constructed markets. It is inevitably the case there will be at least some circumstances in which preservation value will be large relative to use value and if constructed market valuation is not to

\footnotetext{
${ }^{10}$ For an excellent lead-in to the history and methodology of contingent valuation see Portney (1994). His overview piece is followed by several articles both pro and con by various experts.
} 
be allowed, preservation/existence values will be ignored in environmental policy regardless of their magnitude.

Summarizing to this point, there are strong theoretical reasons to suspect that both use and non-use benefits are understated in environmental benefit-cost analyses (because a freeriding sub-optimal income is assumed to be optimal), and moreover use values are likely to dominate environmental policy, even when true preservation/existence values are larger (because of the reluctance to accept constructed market valuations). Are there further reasons to suspect that even the use values themselves are measured with downward bias?

\section{Valuation Methods in Common Use and the Role of Damage Perceptions}

Apart from voting/referenda methods, ${ }^{11}$ there are two primary valuation methodologies in widespread use in environmental benefit-cost analysis. The most intuitively obvious is referred to here as the "Sum of Specific Damages Approach" (sometimes this is referred to as "The Health Effects Model," because typically only health effects are analyzed). The second approach looks at relationships between environmental goods and ordinary goods to infer the former's value and is widely known as "The Hedonic Method."12 Within each approach there is substantial likelihood that important benefits will be ignored as these methodologies are typically applied. The primary focus here, however, is on the nature of the implicit assumptions underlying each approach and what those strongly-opposing assumptions imply about true willingness-to-pay for improvements in environmental quality.

\footnotetext{
${ }^{11}$ Since many environmental benefits (e.g. mortality and morbidity) are concentrated among a small number of individuals, their intensity of want fails to be picked up in a one-person/one vote mechanism. Benefit-cost analysts attempt to aggregate benefits and costs weighting each individual by dollar willingness-to-pay not weighting each individual identically, so I forego discussion in the main text of, for example, California's green propositions.

${ }^{12}$ There are many detailed reviews of both of these approaches, but here are two recent ones: http://papers.ssrn.com/sol3/papers.cfm?abstract id=1542074 (Sum of Specific Damages) http://papers.ssrn.com/sol3/papers.cfm?abstract_id=1542072 (The Hedonic Method)
} 


\section{The Sum of Specific Damages Valuation Method}

The idea under the SSD approach is to first gauge how much an environmental policy will reduce physical damages, $\Delta \mathrm{D}_{\mathrm{i}}$, of a wide variety. There are hundreds of studies relating various levels and types of pollution (e.g. particulates, sulfur dioxide, ozone, or lead) to physical damages taking many forms, such as asthma, cancer, cardiovascular disease, chronic bronchitis, hospital admissions, lead neurotoxicity and blood pressure effects, mortality, respiratory infections, and work loss. A dollar value, $\$ \mathrm{~V}_{\mathrm{i}}$, is then placed on each category of damage, with for example a prevented life lost being valued at perhaps $\$ 5$ to $\$ 7$ million, and the prevention of an asthma attack much less.

The marginal benefits of the policy are, then, the sum of all of the reductions in physical effects times their respective values:

1) Marginal benefits $=\sum\left(\Delta \mathrm{D}_{\mathrm{i}}\right) \$ \mathrm{~V}_{\mathrm{i}}$

The reduction in physical damages is usually further decomposed into:

2) $\Delta \mathrm{D}_{\mathrm{i}}=\mathrm{b}_{\mathrm{i}} * \mathrm{POP}_{\mathrm{i}} * \Delta \mathrm{EQ}$

where: $\Delta \mathrm{D}_{\mathrm{i}}=$ change in population risk for health effect $\mathrm{i}$,

$b_{i}=$ slope of the dose-response function for health effect $i$,

$\mathrm{POP}_{\mathrm{i}}=$ population at risk for health effect $\mathrm{i}$,

$\Delta \mathrm{EQ}=$ change in environmental quality, measured as pollution reduction.

Illustrating, suppose that an environmental policy is being contemplated that is expected to lower fine particulate pollution levels by 5 micrograms per cubic meter in some populous region. Assume that the net present value of the benefits of this change in air quality is one life per million people and the elimination of 100 cases of chronic bronchitis per million people. If 
there are eight million people in the region affected by the policy, then 8 lives will be saved and 800 cases of chronic bronchitis will be eliminated in present value.

Further assume that a saved life is "worth" \$5-7 million dollars, with a best point estimate guess of $\$ 6$ million and an eliminated case of chronic bronchitis is worth $\$ 50,000$ (perhaps based on contingent valuation or some other stated preference mechanism as discussed in earlier). Then the policy would have present benefits of $8 \times \$ 6,000,000+800 \times \$ 50,000=\$ 88,000,000$. If these are the only benefits of the policy and it can be put in force for a present cost of $\$ 88$ million or less, it would be efficient to adopt the policy since it would have marginal benefits greater than or equal to marginal costs, a positive net present value.

The preceding example can be used to illustrate all three major problems with the SSD approach. First, the physical effects due to the policy, $\Delta \mathrm{D}_{\mathrm{i}}$, are highly uncertain; although we "supposed" that 8 people would not die and 800 would not acquire chronic bronchitis if the policy were put into effect, such estimates are very uncertain. In testimony prior to the implementation of the environmental policy, some experts may argue that the damages prevented will be large, while others will argue that the damages prevented may be very small. In part this stems from advocacy positions-an expert working for the American Lung Association is more likely to predict more bronchitis cases prevented by the policy than an expert working for the National Association of Manufacturers. The final determination of damages will likely depend on some mix of the credibility/credentials of the experts and the quality of the analyses they present.

Where do experts of either stripe get their information? There are three primary approaches (toxicological, clinical, and epidemiological) with epidemiological studies tending to carry the most weight. Clinical studies are used to address research questions that can be well 
examined in laboratory settings. In a human clinical study, scientists investigate the effects of individual air or water pollutant "doses" by measuring a variety of health effects (e.g., lung function, heart rate variability, blood component analysis). Clinical studies are themselves usually initiated in response to prior biological studies, either in vitro or in vivo in animal surrogates for humans. The latter provide information about the way pollutants generate their molecular effects, and such animal and in vitro studies are particularly important when human data is unavailable or when such data cannot be ethically obtained.

Epidemiological studies, while less rigidly controlled, offer more natural settings through the statistical analysis of data from human populations or by field studies. In some cases, researchers follow fairly large groups of individuals and use detailed questionnaires to relate the incidence of various disease endpoints to pollutant levels. Field studies involve fewer individual observations and employ repeated assessments of health effects of pollution exposure. The smaller numbers of subjects involved in field studies allow researchers to extend the information obtained in large scale epidemiological studies by including measurements of clinical health endpoints. Various epidemiology studies have, for example, implicated particulate matter in premature death among elderly individuals with cardiopulmonary disease and to increased use of medications, doctor visits, and hospital visits for individuals with pulmonary disease such as asthma.

Toxicology studies attempt to identify and study the specific properties and constituents of various pollutants that are responsible for causing adverse health effects. Toxicologists test the molecular, cellular, and systemic effects of pollutants in experimental settings using cell and tissue cultures, animals, and computer models. As already indicated, findings of dose-response 
effects from a toxicology study might prompt the initiation of either or both clinical trials and epidemiological investigations.

Knowledge is gained from the various approaches, but there remains great uncertainty at the policy level about how physical effects relate to pollution exposures. This is particularly so for chronic pollution effects, such as perhaps a long-latency cancer, vis-a-vis the more immediate acute effects. When certain physical effects are difficult, for various reasons, to tie to pollution, they will tend to be ignored in the SSD approach, leading to understatement of damages. Death or cancer at least have clear definitions, but certain forms of pain, dermatitis, neurological effects, various endocrine disruptions and the like are difficult even to quantify, let alone relate to pollution, hence are likely to be ignored in practice.

Returning to the example of how Equation 2) might be used (or misused), the second source of uncertainty is on what values to place on the physical effects that are predicted to occur. Is the "value of statistical life" (VSL) \$6 million? Or, is it one-tenth or ten times that? Could the value of a chronic bronchitis case be an order of magnitude greater or smaller than the $\$ 50,000$ used in the illustration? One might argue that values such as these are at least plausible, and one could make a fairly strong case for the argument that there is greater uncertainty regarding the physical effects estimated by the epidemiologist than there is regarding the values placed on them by the environmental economist.

Neither of the uncertainties discussed to this point would seem to point to any obvious downward bias in damage estimates. There are two important reasons to suspect that such a downward bias exists, however. First, the physical effects should be all of the physical effects that will occur as a result of the policy, not just (a portion of) the health effects. If a policy cleans up the air or water, it will have physical benefits of a wide variety, not just mortality and 
morbidity benefits. There will generally be ecosystem improvements, agricultural crop yield benefits, material damage reductions (e.g. house painting with less frequency), benefits for pets, as well as aesthetic effects (e.g. smells, visibility). Since we get all of those effects as a result of the policy they all should be counted, yet in practice they never are.

There is an additional theoretical and practical problem with the SSD approach that strengthens the claim that too little environmental quality will be produced if this approach is used to estimate the benefits of environmental policies. For this method to "work well" as a measure of pollution damages, people have to be unaware that pollution has any impact on the damages. That is, the impact of pollution on, say, health has to either be unknown to households or they must be unable to determine where it is clean and dirty. The environmental source of the damages has to be unperceived.

If the damage and its cause were perceived by individuals, they would be expected to engage in costly mitigating behavior" ${ }^{13}$ (sometimes referred to as "averting" behavior), to the point where marginal benefits of mitigation equaled marginal costs of mitigation - and the saved mitigation costs should be added to the marginal benefits of the environmental policy. Since such mitigation costs never are added to environmental benefits calculated by the SSD, analysts are at least implicitly assuming that such costs do not exist, i.e. that individuals do not perceive the causes of their health damage.

We turn now to an approach to valuing environmental improvements that relies on a polar opposite assumption, namely that damages from environmental pollution (hence benefits of environmental pollution cleanup) are perfectly perceived.

\footnotetext{
${ }^{13}$ We might not, for example, exercise outside on high pollution days, we might install dust filters or air conditioning in part to avoid air pollution, we might move to a less-preferred but cleaner location, and so on. In the case of water, we might buy distilled water, or install water filters, as a means of avoiding damages from polluted surface reservoirs or aquifers. In all of these cases, scarce resources are expended to avoid a damage that otherwise would have happened.
} 


\section{The Hedonic Valuation Method}

Two ways that people can avoid pollution damages are by locating in cleaner towns and/or by locating in cleaner parts of a given town. The appropriate use of this method is taken up in some detail here, since the hedonic method is commonly misused and that misuse generally leads to downward-biased estimates of environmental values.

The fundamental notion underlying all hedonic methods is merely that people like to make themselves as well off as possible, exactly the assumptions that we make about their behavior in ordinary markets. Other things equal, we would all prefer to live in a cleaner town or live in a cleaner part of a given town. The idea with hedonic methods is to examine how much households are willing-to-pay in land and/or labor markets to live in cleaner locations, since they will in general have to pay, as we shall see. The main ideas are really quite simple, but to gain a clear understanding of this method we shall first consider wage and rent compensation separately (as is often done, though this is in general incorrect as we shall see). An "integrated" model that was first formally presented by Roback (1982) and later implemented empirically by Blomquist, Berger, and Hoehn (1988) is then described in some detail.

\section{A) Hedonic Methods: Wage Compensation}

Some labor market regions are more polluted than others, and households will have to be compensated for the pollution they experience to be willing to work in dirtier cities. That is, if City A (one of two otherwise identical cities) has higher pollution levels than City B, residents would move from A to B reducing the labor supply in A (raising wages) while increasing the labor supply in B (lowering wages). The movements would continue to occur until the wage differential just compensated people for the higher average pollution in City A. One extremely desirable feature of this approach is that it gives us exactly what we want, the net present value 
of marginal willingness-to-pay in dollar terms, which can then be compared to the marginal costs of policies yielding that amount of cleanness.

The actual process requires as much data as possible on individual wages as well as the determinants of wages for people at various locations (education, experience, age, occupation, region, union, etc.) to which are added measures of environmental quality levels in those locations. With this information accumulated a regression analysis is then performed to statistically relate the wage (as the dependent variable) to those determinants. There is little theoretical guidance on functional form-degree of linearity, interactions among variables, and so on. This raises the possibility that researchers inadvertently, and advocates deliberately, might distort environmental values by their choices along a number of dimensions.

The coefficients on the environmental quality variable will indicate how much impact a given change in environmental quality has on wages, holding constant other wage determinants. In this way, the trade-offs between environmental goods and other goods that people also value can be directly measured. Since higher levels of environmental quality are a desirable trait of a labor market area, we would expect that wages would be lower in the high-environmental quality locations since the supply of labor would be greater to such areas. If environmental quality differences across labor market regions are not perceived or if people don't know how environmental quality affects them, the true benefits of cleaning up will be understated by this method-one would not expect households to accept wage cuts for unperceivable benefits. However, a large number of wage studies (see Bockstael and McConnell 2007 for a nice review in the present context) indicate that households are willing to give up wages to live in cleaner locations. 


\section{B) Hedonic Methods: Property Value or Rent Compensation}

The property value/rent compensation method of hedonic valuation translates the logic that underlies the labor market studies to the housing market. How much a house will sell or rent for is clearly related to the nature of the traits that the house possesses. Some of those traits are "structural," such as whether it is constructed from stone or wood, square footage, number of bathrooms, size of lot, presence of pool or tennis court, type of heat, and so on. Other traits relate to location such as "neighborhood" variables (school quality, freedom from crime, access to various destinations, and so on). These latter traits are "location-fixed" public goods whose prices end up being bundled together into the price of the house along with its structural traits. Environmental quality, viewed from this perspective, is just another location-fixed trait that is desirable from a household's perspective.

Assuming perceptions are perfect and that we have a competitive housing market, the value of clean air must be paid for in higher prices for houses in areas having higher air quality. If we can determine how much people are willing to pay for an otherwise identical home in a clean location versus a dirty location, we will again have a measure of exactly what we want, the present value of the marginal dollar willingness-to-pay for environmental quality, which can then be compared to the present dollar marginal cost of environmental quality.

The process is quite similar to the wage hedonic approach, first requiring as much information as possible about the traits-structural, neighborhood, and environmental quality-of all houses (in what is hopefully a large sample), along with their property values and/or contract rent. In an ideal world, the property value (the dependent variable) would be the actual sales price, but sometimes information is used from multiple-listing books, scaled up or down by the going ratio of list price to exchange price. The property value is next regressed against its 
structural and neighborhood determinants. The empirical analysis involves many possible functional forms, with non-linearities, synergisms, and the like possibly being important. As with the wage hedonic approach, there is little theoretical guidance on the nature of the functional relationship between property values and their determinants which enables researchers accidentally — and advocates intentionally — to publish very different conclusions, even from identical raw data. The coefficients on the environmental quality variables reveal how much impact a given change in environmental quality will have on property values for average households. That is, the trade-off between environmental quality and other goods can be directly measured, and since higher environmental quality is a desired trait, we expect to observe higher house prices or rents in cleaner areas, other things equal.

As with wage studies, property value studies suffer from problems stemming from the assumption of perfect information. Suppose that people don't fully perceive the impact of pollution on their health and well-being or how the pollution levels vary across locations or both. The first possibility is quite plausible, since even the "experts" have widely varying opinions about the amount of physical damage, particularly health damage stemming from pollution, as discussed in the section on the sum-of-specific damages approach. As to the second possible perceptual difficulty, many pollutants are odorless, colorless, and tasteless in ambient concentrations commonly encountered, so it might be difficult for the average person to even know whether a particular house is in a high-pollution or low-pollution location. If buyers don't properly perceive all of the damages from pollution or if they cannot tell which locations are dirtier, the benefits estimated by this approach will be understated. As with the case of wage compensation, people will not be expected to pay for something without tangible benefits. Many 
studies, however, show strong positive relationships between property values and environmental quality.

\section{C) Wage and Property Value Differentials Are Not Alternatives}

Until fairly recently, the preceding hedonic approaches to valuing environmental improvements were viewed as alternative approaches. That is, it was thought that one could find out what clean air was worth either by examining property value variation in land markets or by examining wage variation in labor markets. The approaches were viewed as alternative ways of measuring the same environmental preferences. Indeed, if the values happened to be similar under the two methods, greater confidence was placed in either as a measure.

It turns out that this is incorrect under plausible assumptions about peoples' behavior when evaluating locations. Indeed, for this view to be valid, it must be the case that people follow a two-stage procedure in picking a location. First, only looking at wages (and average pollution levels), they pick a location among alternative labor markets; only then, having settled on a labor market, do they select a location within that labor market based on housing price and pollution variation within that area. This would clearly be irrational since households would do much better in general by looking at the combination of wages, rents, and amenities available in all locations prior to selecting their location.

Another way to think about this is that, between two otherwise identical locations, the one that is more polluted will be less attractive, so people will move from the more-polluted to the less-polluted location until they are equally well off in both locations. But, as they move into the less-polluted location they both increase the supply of labor (driving down wages) and increase the demand for land (driving up rents). Hence, the "true" value of the less-polluted 
locations is the sum of what is being paid for reduced pollution in both the labor and land markets.

At the level of theory, the preceding has been known since at least 1982, with convincing empirical verification being provided by $1988 .^{14}$ Yet many recent studies continued, and continue at this time, to be conducted employing a single-market compensation methodology. This is perhaps partly because the data for such studies is typically easier to come by when only one market is employed, but also partly because it is possible that compensation for specific environmental amenities can occur in either the land or labor market separately. ${ }^{15}$

Clarifying, what is an amenity to households might be a disamenity to firms (e.g. a city introducing an expensive pollution control policy that helps households but harms firms). In this case, wages will definitely be lower (households enter increasing labor supply, while firms exit reducing labor demand), and the effect on property values/rents is ambiguous, depending on whether the city becomes larger or smaller as a result of the policy. Similarly, if an environmental policy happened to be good for both firms and households (e.g. reductions in fine particulate that improve health and perhaps lower production costs of microchips), the benefits to households would appear largely in property values, with perhaps negligible impact on wageswhether wages would rise or fall would depend on whether the amenity was relatively more important to households or to firms.

\footnotetext{
${ }^{14}$ Roback (1982) first presented the theoretical arguments for multi-market amenity compensation in a convincing way, while Blomquist, Berger, and Hoehn (1988), in a large study funded by the EPA, demonstrated empirically that proper valuation of environmental goods requires the summation of compensation in both labor and land markets; moreover, they found that there is wage variation even within large labor market areas using county-level data. In an excellent recent empirical study Kuminoff (2007) finds, in a nested analysis comparing results from a traditional property value approach, that his "new 'dual-market' framework increases estimates for the average per/household marginal willingness-to-pay by as much as $110 \%$."

${ }^{15}$ Indeed, it is the case that the compensation shares are not even limited to being between zero and unity. That is, depending on how important the amenity is for firms relative to households, it is possible to have 150 percent of the amenity value occur in one market and -50 percent occur in the other.
} 
It seems quite likely that hedonic methods would under-state the value of environmental quality improvements, even if a properly-conducted multi-market methodology were employed. The most obviously damaging observation is that the benefits of environmental quality must be fully perceived by households for them to be willing to pay more for cleaner locations. As indicated earlier, even the world's foremost health experts have spirited debates about the role various pollutants play in human disease and death. It seems implausible that ordinary people would be able to accurately perceive such things-moreover, since many pollutants are not detectable by our senses in normal ambient concentrations, it is not even likely that ordinary people would be able to distinguish the clean places from others.

Why do hedonic property value and wage studies show such large environmental effects then? It is certainly the case that people will perceive localized smells, bad visibility, and other impacts of pollution that are inevitably revealed by our five senses. Yet, it is precisely such perceived damages that are ignored in the sum of specific damages (SSD) approach discussed earlier. The SSD environmental valuation method assumes that damages (typically health damages) are unperceived merely occurring to people at greater rates in dirtier locations.

Given the nature of the assumptions about preferences, the two approaches clearly cannot be viewed as alternatives, as is implicitly the case when one methodology is selected in preference to the other. A much stronger case can be made for adding together the damages estimated from an SSD study to those of an hedonic study to get the true damages, those both perceived and unperceived. Such a procedure might result in some double counting, since an area that is unhealthy might also smell bad, but it is likely that the two methods pick up largely unrelated damage categories, those perceivable and those that are not perceivable by households. 
This point is quite important in practical environmental situations, whether in regulatory rulings or in court testimony. The benefits of environmental cleanup are estimated either from a SSD type of approach or an hedonic type of approach, but the estimates are never added together which would in many cases would double the estimated benefits of cleanup.

An additional reason for expecting the hedonic method to understate true benefits is that the hedonic method-even properly conducted-only captures use benefits of the environmental resources of concern, since the amenities are bundled with housing and jobs. As discussed in Section III, non-use benefits might well be of greater magnitude in particular environmental settings, and policies allocating the environmental resource should, on efficiency grounds, encourage highest value allocation-even if that results in "nonuse" of the environmental resources. Illustrating, is the California Coastal Commission properly allocating scarce ocean locations? It is clear that in the absence of this regulatory authority virtually the entire coast of California would be lined with high-rise condos, looking much more like Miami's South Beach area than at present. But, the scenic Pacific Coast Highway has value to all who drive it, and to a large extent that value has been perceived as being of greater importance than the (admittedly very large) benefits households would receive if the coast were opened to unrestricted development. Similar observations would apply to Central Park in New York City.

The final reason why hedonic methods might be expected to understate the benefits of environmental cleanup stems from the relative supplies of clean locations relative to the relative demands for clean locations. The behavior underlying the hedonic method results, at least in principle, in zero spatial consumer surplus. That is, if one location is "nicer" than another location, households will continue to move to the nicer location, until it is no longer nicer-until identical locations have identical full compensation. There will be no consumer surplus over 
space, and indeed this is one of the reasons the hedonic method is desirable in that the full benefits that are perceived are measured. Were people all homogeneous, as the "representative agent" models of economics typically assume, zero consumer surplus over space might well be a reasonable expectation.

But, the fact that people are very different means that understatement of environmental benefits (damage reduction) can occur if there are more locations with the amenity than there are people strongly desiring the amenity. Suppose, for example, that there are very few households containing really sick individuals, individuals with weakened cardio-pulmonary systems who would be highly damaged by pollution. Such households might be willing to pay a great deal for a very clean location, but they might only have to pay a much smaller amount, if the number of "somewhat clean" locations is large relative to the number of these households. They will get

consumers' surplus over space. Inferring the value of cleaning up the environment from the average person in this case would ignore the high marginal benefits received by these households. When one considers the very large number of traits that can matter to a heterogeneous population with very diverse preferences, it becomes clear that a great deal of consumer surplus can remain in the hedonic equilibrium-households are not indifferent to where they locate. In the case of incrementable environmental goods, the unobserved consumer surplus corresponds to a higher marginal value that might-if observed-justify a policy intervention to increase levels of the public good.

\section{Conclusion: Environmental Valuation As Practiced Is Biased Against the Environment}

As an initial observation, we argued that some public goods-such as many environmental goods — will tend to not only lack special interest support, but will actually have powerful special interests aligned against them. Hence initial provision levels are likely to be quite low relative to 
optimal provision levels. Regardless of initial provision level, rational individuals will not generate income to increment a class of environmental goods that are not individually incrementable. These observations imply that benefit-cost analysis of environmental public goods are being conducted with the wrong income levels and all of the ungenerated income would have been spent on environmental public goods, apart from general equilibrium effects.

We then went on to observe that the non-use values, preservation and existence values in particular, are poorly captured by the methods in widespread use by economists. The methods of economics, primarily the sum of specific damages method and the hedonic method, both concentrate exclusively on use values, when it will certainly be the case that some environmental amenities will have a higher value to society collectively if preserved.

Moreover, both of the damage estimation methodologies in common use, the SSD and hedonic methods, understate damage as they are typically conducted. The hedonic approach requires perfect perceptions of environmental benefits along with perfect knowledge of how environmental quality varies over space. Moreover, it remains the case that expert legal testimony and typical regulatory practice still typically employ either a property value study or a wage study, despite knowledge available for more than two decades that compensation for environmental amenities and disamenities will generally occur in both the land and labor markets.

The SSD approach requires zero damage perception to be accurate and, moreover, tends to omit many health and other effects (e.g. material damage, minor health effects, views), while emphasizing acute damages rather than the more difficult to study chronic damages.

A strong case can be made for applying both methods to specific environmental policies being evaluated in a benefit-cost analysis and adding the benefits of a properly conducted 
hedonic analysis to the benefits obtained from the sum of specific damages approach. There might be some double-counting in this process, but it is unlikely that this source of bias would offset the biases within each methodology that lead to understatement of environmental values.

We have focused here almost exclusively on the issues associated with benefit estimation in environmental benefit-cost analysis. There are cost issues as well. Traditionally, many analysts, partly tongue-in-cheek, say that the actual costs will end up being twice what they were predicted to be a priori. But, these casual observations are normally directed at projects (e.g. dams, airports, and the like) that have substantial special interest support and which are, furthermore, usually eligible for federal cost-sharing. Federal cost-sharing creates incentives to pursue projects with local benefits greater than local costs, regardless of overall project efficiency. These projects are politically preferred to typical environmental projects, despite the latter offering learning-by-doing cost savings along with scale economies in provision, suggesting that cost estimates are likely to be overstated for environmental projects. ${ }^{16}$

There are additional reasons, perhaps slightly more speculative than the arguments in the main text sections, for suspecting that benefit-cost analysis of environmental projects is biased against their acceptance. Expected future population growth and likely increases in income have impacts that are generally ignored in environmental benefit-cost analysis. Many environmental policies will confer benefits over long time periods into the future (e.g. it took many years for the catalytic-converter equipped automobiles to predominate on American roads; long-lasting

\footnotetext{
${ }^{16}$ The recent arguments of Hahn (2010) provide an at least partial offset to those of the main text. I would argue that the very pronounced downward bias in benefits discussed here are likely to more than offset any cost-side concerns associated with the regulatory process. Moreover, it is quite easy to find examples of policies in which the costs were a priori argued to be quite high, but were found later to be much lower (e.g. an elaborate 4-point race car seat belt can be acquired for \$10-14 each in quantity and even the less-expensive old-fashioned lap belt reduced traffic fatalities by 30 to 50 percent). As another example, automobile manufacturers expressed great concern about the cost of required catalytic converters on cars built after 1974. Catalytic converter production technology has been systematically improved (e.g. laser welding instead of instead of conventional TIG welding) and prices now range from $\$ 70$ to perhaps $\$ 300$ in various configurations. The catalytic converter has had a huge impact on urban air quality, particularly in rapidly-growing Western cities.
} 
stationary source controls such as baghouses, scrubbers, and the like provide clean air for many years after their introduction). If population growth is occurring at one-percent a year ${ }^{17}$ and per capita income is growing at two-percent a year, the numerator benefits of environmental improvements would be growing at three-percent a year under a conservative assumption that the income elasticity of demand for environmental quality is unity (most economists who have studied this issue would argue that environmental quality is a superior good, with income elasticities of perhaps 1.5).

One of the reasons the preceding observations take on importance is that benefit-cost analyses of environmental policies tend to be only infrequently conducted - a rejection on benefit-cost grounds of an environmental policy at one point in time does not mean that a rejection would occur at a later point in time when population and income are both larger.

When all of the arguments presented here are considered as a whole, it seems difficult to deny that benefit-cost analysis as applied to environmental projects is biased against acceptance of those projects. While the specifics here have dealt with environmental policies, it is likely that the central concerns would apply to many other areas of benefit-cost analysis (e.g. safety, health or natural hazards) where special interest lobbying is either weak or in opposition to "deeper pocket" opposition lobbying.

\footnotetext{
${ }^{17}$ For some countries currently, and many others in the future, population growth may well be negative, which would reverse the text argument. The growth of income is likely to more than offset population declines, however, in the overall growth of numerator benefits from environmental policies.
} 


\section{References}

Blomquist, G.C., G. Berger, and J. Hoehn (1988). New estimates of the quality of life in urban areas. American Economic Review, 78, 89-107.

Bockstael, N.E. and K.E. McConnell (2007). Hedonic wage analysis. Chapter 7 of Environmental and Resource Valuation with Revealed Preferences: A Theoretical Guide to Empirical Models (Volume 7 in the series The Economics of NonMarket Goods and Resources). Springer: Netherlands.

Boyce, R. R., T. C. Brown, G. H. McClelland, G. L. Peterson and W. D. Schulze (1992). An experimental examination of intrinsic values as a source of the WTA-WTP disparity. American Economic Review 82(6), 1366-1373.

Clarke, E.H. (1971). Multipart pricing of public goods. Public Choice. 11, 17.

Flores, N.E. and P.E. Graves (2008). Optimal public goods provision: implications of endogenizing the labor/leisure choice. Land Economics, 84(4), 701-707.

Graves, P.E. (2009) "A note on the valuation of collective goods: overlooked input market free riding for non-individually incrementable goods," The B.E. Journal of Economic Analysis \& Policy: Vol. 9: Iss. 1 (Topics), Article 5.

Available at: http://www.bepress.com/bejeap/vol9/iss1/art5

Or: http://papers.ssrn.com/sol3/papers.cfm?abstract_id=1119316

Groves, T and J.O. Ledyard (1977). Optimal allocation of public goods: a solution to the "free rider" problem. Econometrica. 45, 783.

Hahn, Robert (2010). "Designing smarter regulation with improved benefit-cost analysis," Journal of Benefit-Cost Analysis: Vol. 1: Iss. 1, Article 5. 
Hanemann, W. M. (1991). Willingness to pay and willingness to accept: how much can they differ? American Economic Review 81(3), 635-647.

Horowitz, J. K., and K.E. McConnell, (2002). A review of WTA/WTP studies. Journal of Environmental Economics and Management. 44, 426-447.

Kahneman, D., J. L. Knetsch and R. H. Thaler, (1990). Experimental tests of the endowment effect and the Coase Theorem. Journal of Political Economy 93, 1325-1348.

Kuminoff, N.V. (2007). Recovering preferences from a dual-market locational equilibrium. Manuscript. Department of Agricultural and Applied Economics. Virginia Tech University.

Plott, C.R., and K. Zeiler (2007). Exchange asymmetries incorrectly interpreted as evidence of endowment effect theory and prospect theory? American Economic Review 97, No. 4, (September).

Portney, P.R. (1994). The contingent valuation debate: why economists should care. The Journal of Economic Perspectives. Vol. 8, No. 4, pp. 3-17.

Roback, J. (1982). Wages, rents, and the quality of life. Journal of Political Economy, $90,1257-1278$.

Samuelson, P.A. (1954). The pure theory of public expenditures. Review of Economics and Statistics. 36: 387-389.

Tversky, A. and D. Kahneman (1991). Loss aversion in riskless choice: a reference-dependent model. Quarterly Journal of Economics 104(4), 1039-1062. 


\section{CESifo Working Paper Series}

for full list see www.cesifo-group.org/wp

(address: Poschingerstr. 5, 81679 Munich, Germany, office@cesifo.de)

3081 Stephane Dees, M. Hashem Pesaran, L. Vanessa Smith and Ron P. Smith, Supply, Demand and Monetary Policy Shocks in a Multi-Country New Keynesian Model, June 2010

3082 Sara Amoroso, Peter Kort, Bertrand Melenberg, Joseph Plasmans and Mark Vancauteren, Firm Level Productivity under Imperfect Competition in Output and Labor Markets, June 2010

3083 Thomas Eichner and Rüdiger Pethig, International Carbon Emissions Trading and Strategic Incentives to Subsidize Green Energy, June 2010

3084 Henri Fraisse, Labour Disputes and the Game of Legal Representation, June 2010

3085 Andrzej Baniak and Peter Grajzl, Interjurisdictional Linkages and the Scope for Interventionist Legal Harmonization, June 2010

3086 Oliver Falck and Ludger Woessmann, School Competition and Students' Entrepreneurial Intentions: International Evidence Using Historical Catholic Roots of Private Schooling, June 2010

3087 Bernd Hayo and Stefan Voigt, Determinants of Constitutional Change: Why do Countries Change their Form of Government?, June 2010

3088 Momi Dahan and Michel Strawczynski, Fiscal Rules and Composition Bias in OECD Countries, June 2010

3089 Marcel Fratzscher and Julien Reynaud, IMF Surveillance and Financial Markets - A Political Economy Analysis, June 2010

3090 Michel Beine, Elisabetta Lodigiani and Robert Vermeulen, Remittances and Financial Openness, June 2010

3091 Sebastian Kube and Christian Traxler, The Interaction of Legal and Social Norm Enforcement, June 2010

3092 Volker Grossmann, Thomas M. Steger and Timo Trimborn, Quantifying Optimal Growth Policy, June 2010

3093 Huw David Dixon, A Unified Framework for Using Micro-Data to Compare Dynamic Wage and Price Setting Models, June 2010

3094 Helmuth Cremer, Firouz Gahvari and Pierre Pestieau, Accidental Bequests: A Curse for the Rich and a Boon for the Poor, June 2010 
3095 Frank Lichtenberg, The Contribution of Pharmaceutical Innovation to Longevity Growth in Germany and France, June 2010

3096 Simon P. Anderson, Øystein Foros and Hans Jarle Kind, Hotelling Competition with Multi-Purchasing: Time Magazine, Newsweek, or both?, June 2010

3097 Assar Lindbeck and Mats Persson, A Continuous Theory of Income Insurance, June 2010

3098 Thomas Moutos and Christos Tsitsikas, Whither Public Interest: The Case of Greece's Public Finance, June 2010

3099 Thomas Eichner and Thorsten Upmann, Labor Markets and Capital Tax Competition, June 2010

3100 Massimo Bordignon and Santino Piazza, Who do you Blame in Local Finance? An Analysis of Municipal Financing in Italy, June 2010

3101 Kyriakos C. Neanidis, Financial Dollarization and European Union Membership, June 2010

3102 Maela Giofré, Investor Protection and Foreign Stakeholders, June 2010

3103 Andrea F. Presbitero and Alberto Zazzaro, Competition and Relationship Lending: Friends or Foes?, June 2010

3104 Dan Anderberg and Yu Zhu, The Effect of Education on Martial Status and Partner Characteristics: Evidence from the UK, June 2010

3105 Hendrik Jürges, Eberhard Kruk and Steffen Reinhold, The Effect of Compulsory Schooling on Health - Evidence from Biomarkers, June 2010

3106 Alessandro Gambini and Alberto Zazzaro, Long-Lasting Bank Relationships and Growth of Firms, June 2010

3107 Jenny E. Ligthart and Gerard C. van der Meijden, Coordinated Tax-Tariff Reforms, Informality, and Welfare Distribution, June 2010

3108 Vilen Lipatov and Alfons Weichenrieder, Optimal Income Taxation with Tax Competition, June 2010

3109 Malte Mosel, Competition, Imitation, and R\&D Productivity in a Growth Model with Sector-Specific Patent Protection, June 2010

3110 Balázs Égert, Catching-up and Inflation in Europe: Balassa-Samuelson, Engel's Law and other Culprits, June 2010

3111 Johannes Metzler and Ludger Woessmann, The Impact of Teacher Subject Knowledge on Student Achievement: Evidence from Within-Teacher Within-Student Variation, June 2010 
3112 Leif Danziger, Uniform and Nonuniform Staggering of Wage Contracts, July 2010

3113 Wolfgang Buchholz and Wolfgang Peters, Equity as a Prerequisite for Stable Cooperation in a Public-Good Economy - The Core Revisited, July 2010

3114 Panu Poutvaara and Olli Ropponen, School Shootings and Student Performance, July 2010

3115 John Beirne, Guglielmo Maria Caporale and Nicola Spagnolo, Liquidity Risk, Credit Risk and the Overnight Interest Rate Spread: A Stochastic Volatility Modelling Approach, July 2010

3116 M. Hashem Pesaran, Predictability of Asset Returns and the Efficient Market Hypothesis, July 2010

3117 Dorothee Crayen, Christa Hainz and Christiane Ströh de Martínez, Remittances, Banking Status and the Usage of Insurance Schemes, July 2010

3118 Eric O'N. Fisher, Heckscher-Ohlin Theory when Countries have Different Technologies, July 2010

3119 Huw Dixon and Hervé Le Bihan, Generalized Taylor and Generalized Calvo Price and Wage-Setting: Micro Evidence with Macro Implications, July 2010

3120 Laszlo Goerke and Markus Pannenberg, 'Take it or Go to Court' - The Impact of Sec. 1a of the German Protection against Dismissal Act on Severance Payments -, July 2010

3121 Robert S. Chirinko and Daniel J. Wilson, Can Lower Tax Rates be Bought? Business Rent-Seeking and Tax Competition among U.S. States, July 2010

3122 Douglas Gollin and Christian Zimmermann, Global Climate Change and the Resurgence of Tropical Disease: An Economic Approach, July 2010

3123 Francesco Daveri and Maria Laura Parisi, Experience, Innovation and Productivity Empirical Evidence from Italy's Slowdown, July 2010

3124 Carlo V. Fiorio and Massimo Florio, A Fair Price for Energy? Ownership versus Market Opening in the EU15, July 2010

3125 Frederick van der Ploeg, Natural Resources: Curse or Blessing?, July 2010

3126 Kaisa Kotakorpi and Panu Poutvaara, Pay for Politicians and Candidate Selection: An Empirical Analysis, July 2010

3127 Jun-ichi Itaya, Makoto Okamura and Chikara Yamaguchi, Partial Tax Coordination in a Repeated Game Setting, July 2010

3128 Volker Meier and Helmut Rainer, On the Optimality of Joint Taxation for NonCooperative Couples, July 2010 
3129 Ryan Oprea, Keith Henwood and Daniel Friedman, Separating the Hawks from the Doves: Evidence from Continuous Time Laboratory Games, July 2010

3130 Mari Rege and Ingeborg F. Solli, The Impact of Paternity Leave on Long-term Father Involvement, July 2010

3131 Olaf Posch, Risk Premia in General Equilibrium, July 2010

3132 John Komlos and Marek Brabec, The Trend of BMI Values by Centiles of US Adults, Birth Cohorts 1882-1986, July 2010

3133 Emin Karagözoğlu and Arno Riedl, Information, Uncertainty, and Subjective Entitlements in Bargaining, July 2010

3134 John Boyd, Gianni De Nicolò and Elena Loukoianova, Banking Crises and Crisis Dating: Theory and Evidence, July 2010

3135 Michael R. Baye, Dan Kovenock and Casper G. de Vries, The Herodotus Paradox, July 2010

3136 Martin Kolmar and Hendrik Rommeswinkel, Group Contests with Complementarities in Efforts, July 2010

3137 Carolina Manzano and Xavier Vives, Public and Private Learning from Prices, Strategic Substitutability and Complementarity, and Equilibrium Multiplicity, July 2010

3138 Axel Löffler, Gunther Schnabl and Franziska Schobert, Inflation Targeting by Debtor Central Banks in Emerging Market Economies, July 2010

$3139 \mathrm{Yu}-\mathrm{Fu}$ Chen and Michael Funke, Global Warming and Extreme Events: Rethinking the Timing and Intensity of Environmental Policy, July 2010

3140 Lawrence M. Kahn, Labor Market Policy: A Comparative View on the Costs and Benefits of Labor Market Flexibility, July 2010

3141 Ben J. Heijdra, Jochen O. Mierau and Laurie S.M. Reijnders, The Tragedy of Annuitization, July 2010

3142 Erkki Koskela, Outsourcing Cost and Tax Progression under Nash Wage Bargaining with Flexible Outsourcing, July 2010

3143 Daniel Osberghaus and Christiane Reif, Total Costs and Budgetary Effects of Adaptation to Climate Change: An Assessment for the European Union, August 2010

3144 Philip E. Graves, Benefit-Cost Analysis of Environmental Projects: A Plethora of Systematic Biases, August 2010 